\title{
Infrared Spectra of Nitella Cell Walls and Orientation of Carboxylate Ions in the Walls
}

\author{
Hiromichi Morikawa, Katsuyuki Tanizawa and Mitsugi Senda \\ Department of Agricultural Chemistry, College of Agriculture, \\ Kyoto University, Kyoto 606, Japan
}

Received August 21, 1973

\begin{abstract}
Infrared spectra of film specimens of the cell wall of Nitella were recorded in the untreated state, after acid treatment, and after treatment for removal of pectic substances and hemicellulose. Assignment of the bands in the spectrum of the wall was made. Polarization measuremexts on the wall indicate that in addition to cellulose, carboxylate ions, which are attributable to pectic substances, are oriented in the wall. The nature of the bonds holding the oriented carboxylate ions is described.
\end{abstract}

Internodal cells of fresh-water algae Nitella are very convenient objects for studying cell wall structure and growth. These cells, moreover, are so large that specimens of the cell wall, free from cytoplasmic contamination, can be isolated as a film material and can be measured with comparative ease.

The cell wall of Nitella is a composite material consisting of a number of polymeric substances, i.e. cellulose, hemicellulose, pectic substances and protein. Chemical analysis ${ }^{11}$ showed that the typical composition of the Nitella cell walls used in this study was $35 \%$ $\alpha$-cellulose, $30 \%$ hemicellulose, $25 \%$ pectic substances and $10 \%$ protein. No positive evidence was found to support the presence of lignin in the Nitella cell wall.

Probine and Preston ${ }^{2}$ used infrared spectrometry to identify cellulose I in Nitella cell walls. But no extensive studies on their cell wall composition using infrared spectrometry have been reported. In our study of the cell wall structure of Nitella we recorded infrared spectra of cell walls both in the untreated state and after various treatments. Polarized spectra were also recorded.

\section{EXPERIMENTAL}

As sample materials, internodal cells (usually the third to fifth internodes from the tip )of Nitella axilliformis were used. The plants were collected from a pond at Atsumi and kept in tap water until they were used. The thikness of the wall used in this study ranged from 3 to $7 \mu$ in the wet state. A rectangular strip of cell wall (usually $10 \mathrm{~mm}$ long, parallel to the cell axis, and $1.5 \mathrm{~mm}$ wide) was cut from the cell after plasmolysis. Several strips were accurately aligned under water to overlap and form a sheet covering the opening $(4 \times 10 \mathrm{~mm})$ of the specimen holder of the infrared spectrometer. When dried overnight in the air, the strips adhered to each other and formed a film on the holder. Both ends of the film were cemented to the holder with $\alpha$-cyano acrylates (Toagosei Chemical's Aron Alpha). The thickness of the wall film was several microns when dry. When a treatment, as described below, was wanted, it was given to the wall that had been cemented to the holder.

Infrared spectra of the specimen films were obtained with a Hitachi Model EPI G-3 grating spectrophotometer. Polarization of the infrared radiation was obtained with a Hitachi IRP-21 silver chloride polarizer. The direction of the electric vector of the polarized radiation was always placed at $45^{\circ}$ to the direction of the entrance slit. This setting enabled us to eliminate error in the observed dichroic ratio caused by polarization of the grating monochromators. ${ }^{31}$ When the size of the specimen film was small, a Hitachi Model IRB- 2 beam condenser was used.

Determination of $\mathrm{Ca}^{2+}$ and $\mathrm{Mg}^{2+}$ contents in cell wall was performed by extraction with $1 \mathrm{~N} \mathrm{HCl}$ for $1 \mathrm{hr}$ at room temperature, followed by atomic absorption spectrophotometry. A Hitachi Model 207 atomic absorption spectrophotometer was used. It was previously confirmed by wet ashing method that no appreciable amounts of $\mathrm{Ca}^{2+}$ nor $\mathrm{Mg}^{2+}$ remained in cell walls after extraction as stated above. X-ray fiber diagrams were obtained with a Shimadzu Model GX-3B X-ray diffractometer. As specimen for X- 
ray analysis an accurately alinged and stacked bundle of cell wall strips $(3 \therefore 1.5 \mathrm{~mm}$ ), cut from the same cell, was used and the radiation beam was directed normal to the plane of the wall.

\section{RESULTS AND DISCUSSION}

Figure 1 shows the infrared spectra of Nitella cell walls: (A) in the untreated state; (B) after acid treatment (with $0.01 \mathrm{~N} \mathrm{HCl}$ for $1 \mathrm{hr}$ at room temperature); (C) after treatment for removal of pectic substances (with a mixture of $0.25 \%$ ammonium oxalate and $0.25 \%$ oxalic acid for $1 \mathrm{hr}$ at $85^{\circ} \mathrm{C}$ ); and (D) after treatment for removal of both pectic substances and hemicellulose (with $24 \% \mathrm{KOH}$ for $24 \mathrm{hr}$ at room temperature in nitrogen atmosphere, followed by washing with $0.01 \mathrm{~N}$ $\mathrm{HCl}$ for $1 \mathrm{hr}$ ).

In the spectra, the broad hydrogen-bonded $\mathrm{OH}$ stretching band near $3345 \mathrm{~cm}^{-1}$; the $\mathrm{CH}$ stretching bands near $2900 \mathrm{~cm}^{-1}$; the $\mathrm{CH}$ bending bands near $1375 \mathrm{~cm}^{-1}$; and the $\mathrm{C}-\mathrm{O}$ stretching bands between 1050 and $1165 \mathrm{~cm}^{-1}$ are due to polysaccharides, ${ }^{4}$ i.e. cellulose, hemicellulose and pectic substances. The absorption band at $1425 \mathrm{~cm}^{-1}$ should be due to both $\mathrm{CH}$ bending and $\mathrm{COO}^{-}$symmetric stretching, ${ }^{5,6)}$ which are also attributable to polysaccharides. In spectrum $A$, the absorption band at $1610 \mathrm{~cm}^{-1}$ may be assigned ${ }^{()}$ to the antisymmetric stretching of the $\mathrm{COO}^{-}$ group of hemicellulose and pectic substances. On acid treatment (spectrum $\mathrm{B}$ ), this $\mathrm{COO}^{-}$ band disappears and the $\mathrm{C}=\mathrm{O}$ stretching band due to the carboxyl group at $1735 \mathrm{~cm}^{-1}$ is much intensified, showing conversion of the $\mathrm{COO}^{-}$group to the $\mathrm{COOH}$ group. At the same time two absorption bands at 1640 and $1530 \mathrm{~cm}^{-1}$ become clearly observable. These should be assigned to the amide I and amide II bands, ${ }^{7)}$ respectively, of the cell wall protein. ${ }^{8)}$ Application of the deuteration method enabled us to obtain information on the secondary structure of the wall protein..$^{93}$

On treatment for removal of pectic substances (spectrum C), the intensity of the absorption band of the carbonyl group is largely reduced (see also Table II); whereas, bands at 1640 and $1530 \mathrm{~cm}^{-1}$ remain almost unchanged, showing that wall protein is not extracted by this treatment. On alkali treatment (spectrum D) the carboxyl band at $1735 \mathrm{~cm}^{-1}$ becomes much weaker and the amide bands are also eliminated, i.e. the wall protein together with hemicellulose is almost completely extracted by the alkali treatment. The broad band near $1630 \mathrm{~cm}^{-1}$ in spectrum $\mathrm{D}$ is due to absorbed water, which was confirmed by the deuteraction technique. The broad band near $3450 \mathrm{~cm}^{-1}$ in the spectrum suggests that part of native cellulose I is converted to cellulose II.

Figure 2 shows a polarized spectrum of untreated cell wall. The bands at 3345, 1375 and $1165 \mathrm{~cm}^{-1}$ definitely show perpendicular polarization to the cell axis. The dichroism of these bands polarized parallel to the molecular chains of cellulose has been observed in the spectra of highly oriented

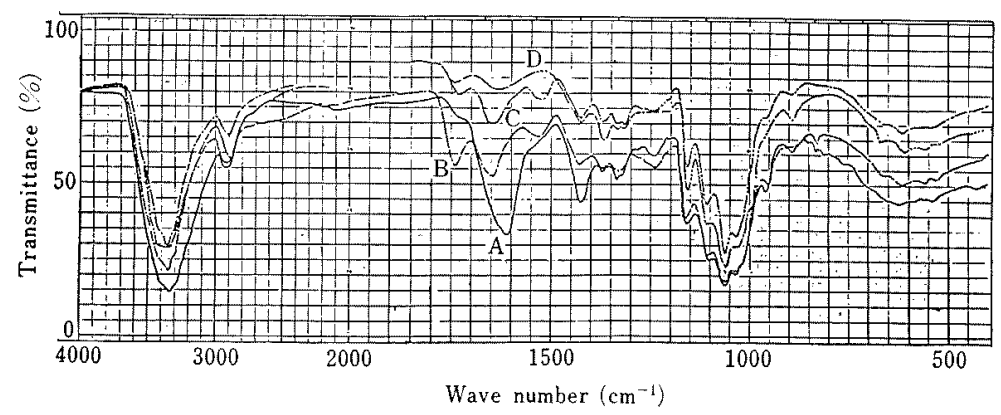

FIG. 1. Infrared Spectra of Nitella Cell Walls.

(A) Untreated, (B) treated with acid, (C) treated for removal of pectic substances, and (D) treated for removal of pectic substances and hemicellulose. 


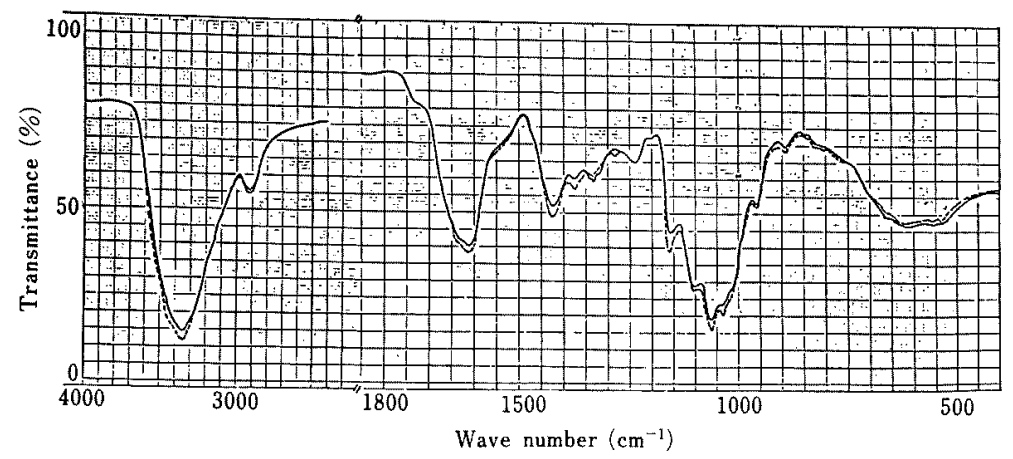

Fig. 2. Polarized Infrared Spectrum of a Nitella Cell Wall in the Untreated State. Full line, E. V.//cell axis; broken line, E. V. $\perp$ cell axis.

crystalline cellulose samples.. ${ }^{5}$ One may thus conclude that the cellulose chains, or the length of the cellulose crystallites, must be preferentially oriented in an almost transverse direction to the cell axis, which agrees with the result obtained by X-ray diffraction analysis. ${ }^{2)}$

The $\mathrm{COO}^{-}$antisymmetric stretching band at $1610 \mathrm{~cm}^{-1}$ also shows perpendicular polarization to the cell axis (see Fig. 2). After treatment for removal of pectic substances, the intensity of this carboxylate ion band was reduced to $40 \sim 50 \%$ of that of the untreated sample (see also Table II). Moreover, the band became unpolarized. Accordingly one concludes that the carboxylate ion, showing perpendicular polarization, originates mainly from uronic acid residues of pectic substances in the wall. Since the transition moment of the $\mathrm{COO}^{-}$antisymmetric stretching vibration may be considered to be in the direction of $\mathrm{O}---\mathrm{O}$ line,${ }^{10)}$ the carboxylate ions in the wall are considered to be oriented preferentially with their O---O lines perpendicular to the cell axis.

In order to clarify the nature of the bonds holding the oriented carboxylate ions in the wall, effect of counterions on the dichroism of $\mathrm{COO}^{-}$band was examined.

The Nitella cell walls used in this study contained $0.58 \pm 0.04 \mu$ moles $\mathrm{Ca}^{2+}$ and $0.080 \pm$ $0.004 \mu$ moles $\mathrm{Mg}^{2+}$ (average of four samples \pm standard deviation) per $\mathrm{mg}$ dry cell wall. When treated with $0.1 \mathrm{~N}$ or $1 \mathrm{~N} \mathrm{NaCl}$ solution for $1 \mathrm{hr}$ at room temperature, the $\mathrm{Ca}^{2+}$ and $\mathrm{Mg}^{2+}$ contents in the wall were reduced to less than $10 \%$ of the original amounts. Some results of the chemical analysis are shown in Table I. Determination of $\mathrm{Ca}^{2+}$ and $\mathrm{Mg}^{2+}$ contents was performed by extraction with $1 \mathrm{~N} \mathrm{HCl}$ for $1 \mathrm{hr}$ at room temperature, followed by atomic absorption spectrophotometry. However, these treatments with $\mathrm{NaCl}$ solutions did not change the optical densities of OH stretching band (near $3345 \mathrm{~cm}^{-1}$ ) and $\mathrm{COO}^{-}$antisymmetric stretching band (near

Table I. Calcium and Magnesium Contents in Cell Wall before AND AFTER TREATMENT WITH $0.1 \mathrm{~N}$ OR $1 \mathrm{~N} \mathrm{NaCl}$ SOLUTION

\begin{tabular}{|c|c|c|c|c|c|c|c|}
\hline \multirow{3}{*}{ No. } & \multirow{3}{*}{$\begin{array}{l}\text { Dry wt. of } \\
\text { cell wall } \\
\text { (mg) }\end{array}$} & \multicolumn{3}{|c|}{$\mathrm{Ca}^{2+}(\mu$ moles $)$} & \multicolumn{3}{|c|}{$\mathrm{Mg}^{2+}(\mu$ moles $)$} \\
\hline & & \multirow[t]{2}{*}{ Untreated } & \multicolumn{2}{|c|}{ Treated with } & \multirow[t]{2}{*}{ Untreated } & \multicolumn{2}{|c|}{ Treated with } \\
\hline & & & $0.1 \mathrm{~N} \mathrm{NaCl}$ & $1 \mathrm{~N} \mathrm{NaCl}$ & & $0.1 \mathrm{~N} \mathrm{Na}$ & $\mathrm{N} \mathrm{NaCl}$ \\
\hline 1 & 3.5 & 1.9 & 0.2 & - & 0.27 & 0.01 & - \\
\hline 2 & 3.2 & 1.8 & 0.2 & - & 0.25 & 0.00 & - \\
\hline 3 & 3.6 & 2.1 & - & 0.0 & 0.29 & - & 0.00 \\
\hline 4 & 3.4 & 2.2 & - & 0.1 & 0.29 & - & 0.00 \\
\hline
\end{tabular}


Table II. Changes of Optical Densities OF THE OH AND $\mathrm{COO}^{-}$BANDS NeAR $3345 \mathrm{~cm}^{-1}$ AND $1610 \mathrm{~cm}^{-1}$, RESPECTIVELY, ON TREATMENT WITH $0.1 \mathrm{~N}$ OR $1 \mathrm{~N} \mathrm{NaCl}$ SOLUTION OR $0.25 \%$

AMMONIUM OXALATE $+0.25 \%$ OXalic ACID SOlution

\begin{tabular}{lcc}
\hline & $\begin{array}{c}\text { O.D. of } \\
\text { OH band }\end{array}$ & $\begin{array}{c}\text { O.D. of } \\
\text { COO }^{-} \text {band }\end{array}$ \\
\hline $\begin{array}{l}\text { Control } \\
\text { Treated with }\end{array}$ & $100 \%$ & $100 \%$ \\
$0.1 \mathrm{~N} \mathrm{NaCl}$ & $100 \pm 8(5)^{a)}$ & $102 \pm 7(5)^{a)}$ \\
Treated with & $90 \pm 8(5)$ & $98 \pm 7(5)$ \\
IN NaCl & & \\
$\begin{array}{l}\text { Treated with } \\
\text { o.25\% amm. } \\
\text { oxalate }+0.25 \% \\
\text { oxalic a. }{ }^{b 1}\end{array}$ & $70 \pm 9(5)$ & $45 \pm 9(5)$ \\
\hline
\end{tabular}

a) Values in parentheses are the numbers of experiments.

b) Treated with $0.25 \%$ ammonium oxalate $+0.25 \%$ oxalic acid solution for $1 \mathrm{hr}$ at $85^{\circ} \mathrm{C}$, then washed with $0.1 \mathrm{~N} \mathrm{CaCl} 2$ solution for $1 \mathrm{hr}$ at room temperature and with distilled water.

$1610 \mathrm{~cm}^{-1}$ ) of the cell wall, though the absorption peak of the latter band shifted slightly to lower frequency (see Table III). The infrared results are shown in Table II. Removal of pectic substances reduced the optical densities of $\mathrm{OH}$ and $\mathrm{COO}^{-}$bands to $70 \pm 9 \%$ and $45 \pm 9 \%$, respectively, of those of the control. One may therefore conclude that most of $\mathrm{Ca}^{2+}$ and $\mathrm{Mg}^{2+}$ ions can be exchanged with $\mathrm{Na}^{+}$ions rather easily, but pectic substances remain insoluble in the wall. This conclusion is in harmony with the recent idea ${ }^{11)}$ that the bonds holding pectic substances in cell wall are not exclusively ionic bridging with divalent cations.

Table III shows dichroic ratios and frequencies of absorption maximum of antisymmetric stretching band of $\mathrm{COO}^{-}$ions in cell wall, before and after treatment with $0.1 \mathrm{~N}$ solutions of chloride salts of various mono-, di- and trivalent cations. The cell walls were treated with $0.1 \mathrm{~N}$ salt solution for $1 \mathrm{hr}$, then were washed with $95 \%$ ethanol (in case of monovalent cation) or with distilled water. After being left to dry overnight, their polarized infrared spectra were measured. The absorption maxima of $\mathrm{COO}^{-}$band shifted to
Table III. Dichroic Ratios and Frequencies of Absorption Maximum of the ANTISYMmetric Stretching Band of $\mathrm{COO}^{-}$IONS IN THE Wall, after Treatment With $0.1 \mathrm{~N}$ Chloride Salt Solutions

\begin{tabular}{lccc} 
& \multicolumn{2}{c}{ Dichroic ratio } & \\
\cline { 2 - 3 } & Control & Treated & $\begin{array}{c}\text { Frequency } \\
\left(\mathrm{cm}^{-1}\right)^{a 1}\end{array}$ \\
\hline $\mathrm{Li}^{+}$ & 1.07 & 1.06 & 1610 \\
$\mathrm{Na}^{+}$ & 1.05 & 1.05 & 1605 \\
$\mathrm{~K}^{+}$ & 1.05 & 1.05 & 1600 \\
$(\mathrm{Et})_{4} \mathrm{~N}^{+}$ & 1.08 & 1.08 & 1605 \\
$\mathrm{Mg}^{2+}$ & 1.06 & 1.02 & 1635 \\
$\mathrm{Ca}^{2+}$ & 1.07 & 1.09 & 1610 \\
$\mathrm{Ba}^{2+}$ & 1.08 & 1.08 & 1600 \\
$\mathrm{Al}^{3+}$ & 1.08 & 1.07 & 1610 \\
$\mathrm{La}^{3+}$ & 1.10 & 1.06 & 1600 \\
$\mathrm{Average}^{+}$ & $1.07_{1} \pm 0.01_{5}$ & $1.06_{2} \pm 0.02_{0}$ & - \\
\hline
\end{tabular}

a) Control; $1610 \mathrm{~cm}^{-1}$

higher frequency with increasing electronegativity each for the series of mono-, di- and trivalent metal ions. Their orders of the shifts of absorption maxima are identical to those that have been observed with mono- and divalent metal ion salts of fatty acids. ${ }^{12,13)}$ These results are consistent with the result by chemical analysis that $\mathrm{Ca}^{2+}$ and $\mathrm{Mg}^{2+}$ ions in the walls were exchanged almost completely with the cations of the salts used in the treatment. On the other hand the dichroic ratios of the carboxylate ion band were found to be hardly affected by the size and valency of the exchanged ions. It may be concluded therefore that the counterions are bound with the carboxylate ions, but that the force holding the carboxylate ions in oriented structure is not of ionic nature, e.g. by ionic bridging, but of non-ionic nature.

The X-ray fiber diagram of a Nitella cell wall was measured but no definite diffraction pattern, other than that of cellulose, was observed. Therefore, the lattice order of the molecular chains, if any, would not be suffciently high to give an X-ray diagram. Infrared evidence for the orientation of some groups of xylan in birch wood sections has been reported by Marchessault and Liang," 


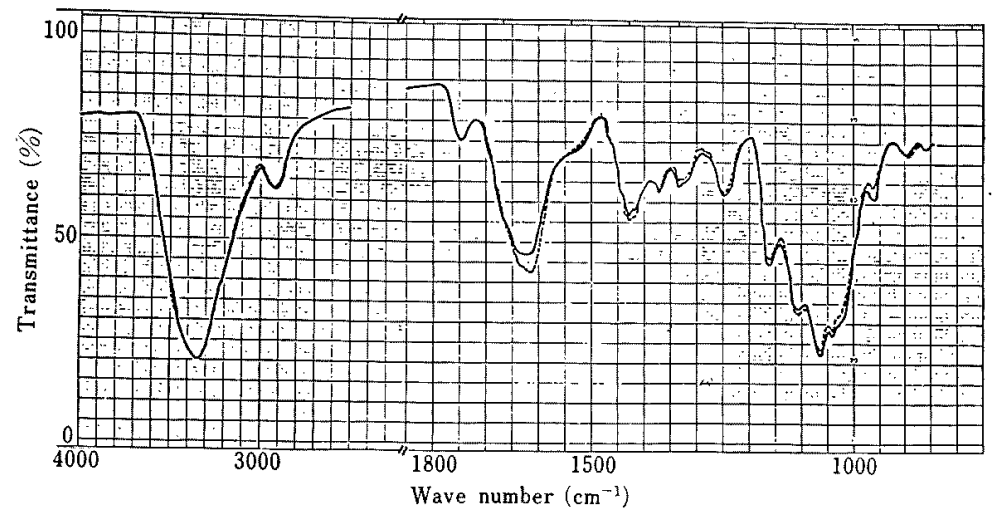

FIG. 3. Polarized Infrared Spectrum of a Nitella Cell Wall Stretched along the Cell Axis. Full line, E. V.//cell axis; broken line, E. V. $\perp$ cell axis.

who attributed this to the orientation of molecular chains of xylan, though incapable of giving an X-ray diagram. According to Rees and Wight, ${ }^{14)}$ however, in pectic substances anomalous units (usually L-rhamnose residues) are interspersed to form kinks which interrupt any tendency to an ordered chain conformation. Thus a possible interpretation of the presence of oriented carboxylate ions in the wall would be that the carboxylate ions of pectic substances are arranged in close connection with the oriented molecular chains of the cellulose fibrils, probably by hydrogen bonding or solvation-like bonding with $\mathrm{OH}$ groups on the surface of cellulose microfibrils.

It has been reported ${ }^{15)}$ that the cell wall is deformed by applying fixed loads, where the molecular chain mesh of incrusting substances is distorted as well as the arranged structure of cellulose microfibrils. Hence, the following experiment was performed.

Strips of cell wall were clamped at each end and stretched longitudinally with a fixed load (about $170 \mathrm{~g} /$ three strips) for several hours in water, where the extention was about $10 \%$. After being left to dry overnight under the loads, the strips were fixed on the holder, then were measured for infrared absorption. As shown in Fig. 3, one observed that polarization of the cellulose bands was considerably weakened (e.g. near $3345 \mathrm{~cm}^{-1}$ ) or even reversed (e.g. at $1165 \mathrm{~cm}^{-1}$ ). This indicates a change in the orientation of cellulose chains from a preferentially-transverse orientation to a random or preferentially-longitudinal one during the creep. However, polarization of the carboxylate ion band near $1610 \mathrm{~cm}^{-1}$ was retained or even strengthened. Thus, orientation of the carboxylate ions is not distorted but retained or even improved during the creep. These phenomena are interesting in view of the creep theory of the extension growth of the cell wall. ${ }^{15}$ Further study is in progress in this laboratory.

Acknowledgement. We wish to thank Prof. $\mathbf{H}$. Harada and Prof. T. Takenaka for their interest in and encouragement of this study. We also wish to thank Prof. T. Mitsui for the use of the infrared spectrophotometer in his laboratory, and Assoc. Prof. K. Okamura for his valuable advice about X-ray analysis.

\section{REFERENCES}

1) To be published in another article.

2) M. C. Probine and R. D. Preston, J. exp. Bot., 12, 261 (1961).

3) M. Tsuboi, J. Polm. Sci., 59, 139 (1962).

4) C. Y. Liang, K. H. Basset, E. A. McGinnes and R. H. Marchessualt, TAPPI, 43, 1017 (1960); R. H. Marchessault, Pure appl. Chem., 5, 107 (1962).

5) C. Y. Liang and R. H. Marchessault, J. Polm. Sci., 37, 385 (1959); idem, ibid., 39, 269 (1959).

6) R. H. Marchessault and C.Y.Liang, ibid., 59, 357 (1962).

7) T. Miyazawa, "Poly-a-Amino Acids," ed. by G. D. Fasman, Marcel Dekker, New York, 1967, p. 69.

8) E.W. Thompson and R. D. Preston, Nature 
Lond., 213, 684 (1967).

9) To be published in another article.

10) S. Mizushima and T. Shimanouchi, "Infrared Absorption and Raman Effect," Kyoritsu Publ. Co., Tokyo, 1958.

11) D. A. Rees, Adv. Carbohydrate Chem. Biochem., 24, 267 (1969).

12) Y. Koga and R. Matuura, Memo. Fac. Sci.,
Kyushu Univ., c4, 1 (1961).

13) R. Gotoh and T. Takenaka, Nippon Kagaku Zasshi, 84, 392 (1963).

14) D. A. Rees and A. W. Wight, J. Chem. Soc. B, 1971, 1366.

15) M. C. Probine and R. D. Preston, J. exp. Bot, 13, 111 (1962). 